\title{
Magma storage beneath Ardestan pluton, Iran; Insights from silicate minerals, zircon signatures and crystal size distribution
}

\author{
SHAHROUZ BABAZADEH ${ }^{1}$, TANYA FURMAN ${ }^{2 *}$, \\ JOHN M. COTTLE ${ }^{3}$, DAVOOD RAEISI ${ }^{4}$, IANNA \\ LIMA $^{2,5}$ \\ ${ }^{1}$ Research Institute for Earth Sciences, Tehran 13185- \\ 1494, Iran \\ ${ }^{2}$ Department of Geosciences, Pennsylvania State \\ University, University Park, PA 16802, USA; tfl3@psu.edu \\ ${ }^{3}$ Department of Earth Science University of California, \\ Santa Barbara, CA 93106-9630, USA \\ ${ }^{4}$ University of Tehran, Tehran, 14155-64155, Iran \\ ${ }^{5}$ Department of Geosciences, Federal University of Mato \\ Grosso, Cuiabá, Brazil
}

Crystal cargo origins and bulk rock Zr-based thermometric parameters are fundamental to developing petrogenetic models of magmatism. The Ardestan quartz diorite to tonalite pluton, part of widespread Cenozoic magmatism within the Urumieh-Dokhtar magmatic arc, yielded LA-ICP-MS zircon age of $25.9 \pm 0.3 \mathrm{Ma}$ and $24.6 \pm 0.1 \mathrm{Ma}$, respectively. The studied rocks are mainly composed of varying proportions of plagioclase feldspar (bytownite in the core to labradoriteandesine composition at the rim), magnesio-hornblende and magnesio-biotite. Zircons are depleted in LREE and enriched in HREE with restricted ranges in $(\mathrm{Gd} / \mathrm{Yb})_{\mathrm{N}}(0.03-0.07)$, positive $\mathrm{Ce}$ anomalies $\left(\mathrm{Ce} / \mathrm{Ce}^{*}=0.4-113\right)$, negative $\mathrm{Eu}$ anomalies $\left(\mathrm{Eu} / \mathrm{Eu}^{*}=0.13-0.30\right)$ and high $(\mathrm{Sm} / \mathrm{La})_{\mathrm{N}}(>10)$ suggesting a magmatic origin. Enrichment in LREEs and moderate to negative $\mathrm{Ce}$ anomalies in some zircons is attributed to a change in the host magma composition and/or crystallization of zircon under high aqueous fluid activity near the end of magmatic crystallization. Ti-in-biotite geothermometery gives a mean crystallization temperature of $730 \pm 56{ }^{\circ} \mathrm{C}$, slightly higher than calculated $\mathrm{T}_{\mathrm{ZrTi}}{ }^{\circ} \mathrm{C}(716 \pm$ $50{ }^{\circ} \mathrm{C}$ ) and similar to the average $\mathrm{T}_{\text {Zr.sat }}{ }^{\circ} \mathrm{C}\left(735 \pm 26^{\circ} \mathrm{C}\right)$. These results provide minimum estimates of temperature and indicate zircon crystallized from a fractionated magma. The resulting estimated $f \mathrm{O}_{2}$ values show fairly high $f \mathrm{O}_{2}$ (i.e., -13.6 to -16.9), indicating oxidizing crystallization conditions between the $\mathrm{Ni}-\mathrm{NiO}(\mathrm{NNO})$ and $\mathrm{Fe}_{2} \mathrm{O}_{3}-\mathrm{Fe}_{3} \mathrm{O}_{4}$ (HM) buffers. Tight linear trends of halogen contents $(\mathrm{F}$ and $\mathrm{Cl})$ versus $\mathrm{X}_{\mathrm{Mg}}$ represent a narrow range of $f \mathrm{H}_{2} \mathrm{O}, f \mathrm{HF}$ and $f \mathrm{HCl}$, clearly indicating that constant physico-chemical conditions throughout biotite growth. $\mathrm{H}$ The shape of crystal size distribution curves and the medium $\mathrm{Al}$ and $\mathrm{Mg}$ contents in amphibole and biotite, respectively, are consistent with a history of magma mixing involving injections of mafic magma into the evolving felsic chamber. Calculated residence time for Ardestan plagioclase crystals of $\sim 630$ years support field evidence that these plutons were emplaced at shallow depths. 